\title{
Prehistory of Northern Africa
}

$\mathrm{A}^{\mathrm{N}}$ $\mathrm{N}$ important study of the archæology and racial history of the western area of North Africa, published by the Institut de Paléontologie humaine,* arises out of the investigation by M. C. Arambourg in the years 1927-30 of a series of caves in the hills which fringe the Gulf of Bougie on the coast of Algeria. Several of these caves were already known to archæologists and palæontologists, and finds in them have been described from time to time, but no systematic investigation had been undertaken previously.

The cave of Afalou-bou-Rhummel is a large shelter of ten metres in depth with an opening about twenty metres wide. Its deposits were first examined by trenching along the axis of the cave to a depth of $9 \cdot 15 \mathrm{~m}$. over a length of 17 metres. The ossuary was found at a depth of between $3.25 \mathrm{~m}$. and $4 \mathrm{~m}$. at about three metres from the south wall. Eight complete skeletons and about fifty skulls were recovered. Another complete skeleton, with the cranium of a child, was found later at a lower level.

The deposits of the eave fall into two sections of which the upper only, reaching to a depth of $7.50 \mathrm{~m}$., contained evidence of human occupation. The lower, archæologically and palæontologically sterile, reaches bed rock through a depth of 8 metres.

The upper stratum of the archæological level to a depth of $4.40 \mathrm{~m}$. contains a uniform industry, of which the chief characteristic is a microlith $\dot{a}$.dos retaille of the 'La Mouillah' type. The food debris consist almost entirely of marine shells. Below is a deposit 1 metre in thickness in which there is no variation in the industry, but the deposits are of a reddish yellow in colour and the debris of food include some bones of the moufflon in addition to the marine shells. Below this is a sterile layer of $50 \mathrm{~cm}$. thickness which overlies the third archæological layer of reddish thickly compacted deposits $1.8 \mathrm{~m}$. thick, in which the animal remains constitute a veritable bone bed. Not only was the food-supply of the inhabitants of this period more varied than that of their successors, but also their stone industry, though essentially identical, was more abundant. Below this the sterile layers begin.

The human remains were found in a state of confusion and many of the bones were calcined. The industry of the archæological levels consists almost exclusively of flint and polished bone-blades, flakes and scrapers. It is virtually identical throughout except that in the upper and later levels there is an increase in the percentage of microliths. Among the molluses which served as food, Patella, Trochus and Helix are very common, and among the mammalia the dorcas gazelle, moufflon and Bos primigenius are frequent.

In the rock-shelter of Tamar-hat, which is now about six metres broad by eight metres deep, but once was much larger, trenching revealed an uninterrupted succession of archæological deposits of more than five metres depth. Here, also, through a succession of five distinguishable levels, there was what is essentially an identity of industry-again with a predominance in the later stages of the small blades. The vertebrates and mollusca appear in the same

* Les grottes paléolithiques des Beni Segoual (Algérie). Par C. Arambourg, M. Boule, H. Vallois, R. Verneau. (Archives de l'Institu de Paleontologie humaine, Memoin. relation as at Afalou, but Hippotragus appears here for the first time in North Africa.

Taking into account certain positive and negative characters, M. Arambourg arrives at the conclusion that the industry from the two cave sites is typically Ibero-Maurusian and comparable with that industry as identified on other sites in North Africa in a distribution extending from Morocco to Tunis. As a result of an analysis of the upper palæolithic stone age of North Africa, he also concludes that the IberoMaurusian industry, lying between Mousterian and Mauretanian neolithic, is to be considered as a facies of the Upper Palæolithic, parallel to the Capsian facies, of which it takes the place on the littoral of Constantine, in Oran, Algeria and Moroceo. This view is corroborated by the identification of Capsian man and Ibero-Maurusian man, now made possible by the discovery of skeletal remains in the cave of Afalou.

M. Arambourg goes on to wider inference that a similar interpretation is to be placed upon the succession of specialised industries of the Upper Palæolithic elsewhere, as, for example, in Kenya and South Africa. These, as the Capsian and the IberoMaurusian, are to be regarded as specialised and locally evolved Aurignacian.

The skeletal material from Afalou is examined by MM. Boule, Verneau and Vallois. It consists of fifty skulls and nine complete or approximately complete skeletons, of which ten are definitely not adult. All the skulls are robust in type, but, with the aid in certain cases of the indications afforded by the pelvis, 26 men and 14 women ean be distinguished among the adults. Thirty-two of the adult skulls are now sufficiently complete for measurement in detail They present a well-marked type. The cranium is of medium form, the face broad and low, with wellmarked glabella and superciliary ridges. The cheek bones and zygomatic arches are massive. There is no prognathism. The maximum length varies from $193 \mathrm{~mm}$. to $206 \mathrm{~mm}$. and breadth from $133 \mathrm{~mm}$. to $159 \mathrm{~mm}$. It will be noted that in breadth they approach that of brachycephalic or mesocephalic peoples of Europe. The mean of the cranial capacity for men is 1,622 c.c., for women 1,456 c.c. Essentially they are dolichocephalic, or mesocephalic, and the sexual difference is insignificant. Evulsion of the upper incisors was practised. Taken as a whole, the remains represent a homogeneous group which, as indicated by the long bones, was of more than average stature. The bones of the skeletons have been subjected to a careful examination, of which the results are described in detail.

As the result of a detailed comparison with the remains of fossil men of palæolithic age found in North Africa and also with 'fossil' man elsewhere, and more especially with the skeletal remains from Mechta el-Arbi, here studied and described as a complete whole for the first time, the authors conclude that Afalou man approaches most nearly to the Cro-Magnon man and belongs to a North African group, here styled "the Mechta type". This type persists through neolithic, bronze and iron ages and reappears in the population of the Canaries. Though it is possibly to be discerned in the Carthaginian and Roman periods, it appears to have contributed nothing to the modern Berber population. 